\title{
Dating Strong Prehistoric Earthquakes and Estimating Their Recurrence Interval Applying Radiocarbon Analysis and Dendroseismological Approach - Case Study from SE Altai (Russia)
}

\author{
Anna Agatova ${ }^{1,2^{*}}$, Roman Nepop ${ }^{1,2}$ \\ ${ }^{1}$ Sobolev Institute of Geology and Mineralogy, 3 Koptyuga Avenue, Novosibirsk, 630090 Russia \\ ${ }^{2}$ Ural Federal University, 19 Mira Street, Yekaterinburg, 620002 Russia
}

\begin{abstract}
Earthquakes are some of the most disastrous geohazards. The recurrence interval of strong earthquakes is a crucial characteristic for seismic hazard risk assessment. In this context absolute age determination of ancient earthquakes is one of the key problems. This paper presents the results of our geomorphological, paleoseismogeological, and geochronological investigations in seismically active southeastern part of Russian Altai. To specify the Holocene recurrence interval of strong earthquakes in the SE Altai we used radiocarbon and tree ring analysis. Twenty-five new radiocarbon ages were obtained for previously unknown effects of prehistoric earthquakes located near the southern fault boundary of the Chagan-Uzun massif and were reactivated during the 2003 Chuya earthquake. Results obtained argue for high regional seismicity in the second half of the Holocene and indicate the ChaganUzun massif to be one of the major seismogenic neotectonic structure within the SE Altai. Strong earthquakes occurred here about 600-700, 1,300-1,500, 2,400-2,700, and 3,400-3,700 and 3,800-4,200 cal. BP. Together with the previously published radiocarbon dates these data clarify the chronology of seismic events within the SE Altai. The specified recurrence interval of strong earthquakes for the SE Altai is about 400 years during the last 4,000 years. Numerous evidences of several seismic excitations were found in sediments from the largest landslide triggered by the 2003 Chuya earthquake. This argues for repeated activization of the same earthquake source zones in the SE Altai during the Holocene. Seismic activization of the fault boundaries of the Chagan-Uzun massif in the late Pleistocene-Holocene, as well as in 2003, was accompanied by its rotation counter clock-wise with the prevailing displacement along dextral strike-slip faults of NW direction. This is supported by results of our geomorphological investigations and previously unknown ground effects of the 2003 Chuya earthquake in the central part of the Chagan-Uzun massif.
\end{abstract}

Keywords: geohazards, paleoseismicity, radiocarbon dating, dendroseismology, recurrence interval of strong earthquakes, Holocene, SE Altai

\section{Introduction}

The evolution of paleoseismogeological studies clearly demonstrates that in order to properly understand the seismic potential of a region, and to assess the associated seismic hazard, extensive studies are necessary to take full advantage of the geological evidence of past earthquakes. The period of instrumental seismological observations is insignificant in comparison with the recurrence interval of strong earthquakes. Thus to achieve these goals the historical data are necessary. Paleoseismogeology supplements historical and instrumental records of seismicity by

* Corresponding Author: Anna Agatova, agatr@mail.ru, Tel: +7 (383) 330-8363 
characterizing strong prehistoric earthquakes. It is focused on studying ground effects (both primary - ruptures, and secondary - gravitational deformations (Solonenko 1973, McCalpin 2009) from past earthquakes preserved in the geologic and geomorphic environment. The recurrence interval of strong paleoearthquakes is a critical characteristic in assessing the regional seismic hazard and seismic risk zoning.

Southeastern part of Russian Altai (SE Altai) is the northern extension of Mongolian Altai which is known for its high seismicity. Detailed paleoseismogeological investigations of 19961999 revealed numerous effects of strong Holocene earthquakes and showed that repeated reactivations of the same earthquake source zones occurred within the SE Altai during the Holocene (Rogozhin and Platonova 2002). The recurrence interval of strong earthquakes was estimated as 1$3 \mathrm{ka}$, which was similar to previously obtained assessment obtained on the basis of geological tectonic and seismological data (Zhalkovsky et al 1978). The 2003 Chuya earthquake $\left(M_{S}=7.3\right)$ with its epicenter in the SE Altai generated a complex system of primary seismotectonic deformations, including a NW trending main rupture about 70 $\mathrm{km}$ in length. It was a dextral strike slip fault with a horizontal displacement up to $2 \mathrm{~m}$, and subsidiary branch faults of reverse and dextral strike slip kinematics. A giant landslide on the right Taldura river bank was the largest seismogravitational deformation triggered by this earthquake. The 2003 Chuya earthquake supported high regional seismicity and encouraged the continuation of paleoseismogeological investigations (e.g. Agatova et al 2006, Rogozhin et al 2007, 2008). On the basis of numerous radiocarbon dates the recurrence interval of strong earthquakes was specified -500 -900 years for the last 9 ka (Rogozhin et al 2007, 2008). Despite the fact that the epicenter zone of the 2003 Chuya earthquake was well studied, ground effects of this seismic event within the Chagan-Uzun massif were not investigated, even though the epicenter of the main shock was located on the southern boundary of this massif. The deposits of the largest triggered landslide also were not sufficiently studied. Numerous new outcrops and ruptures in the landslide body give a unique opportunity to observe paleoseismodeformations of slope sediments.

This paper presents new results of our geomorphological, paleoseismogeological, and geochronological investigations in the epicenter zone of the 2003 Chuya earthquake. Ground effects, parameters of the pleistoseist zone, and kinematics of the 2003 seismic excitation were determined. We also present a number of new radiocarbon dates related to the geological evidence which define the chronology of strong prehistoric earthquakes in the region. These data together with the results of tree ring analysis, which was for the first time utilized in paleoseismogeological researches in SE Altai, and previously published radiocarbon dates allow specifying the recurrence interval of strong earthquakes in the SE Altai for the last 4,000 years.

\section{Regional Settings}

The Altai Mountains are the northern part of the Central Asia collision belt (Fig. 1). They stretch northwest more than $1,500 \mathrm{~km}$ across the borders of Mongolia, China, Kazakhstan and Russia, and form a wedge shape narrowest in the southeast and widest in the northwest. Elevation increases in the opposite direction from 400 to $4,000 \mathrm{~m}$ a.s.1.

Within the neotectonic structure of the Altai Mountains, the southeastern part of Russian Altai (SE Altai) is a transpressional zone formed due to oblique thrusting. Significant lithosphere destruction and block movement along the sublatitudinal reverse faults and thrusts take place here. The SE Altai is the highest part of the Russian Altai and includes the Chuya, Kurai intermountain depressions, located at about 1,750 and 1,600 $\mathrm{m}$ a.s.1. correspondingly, and framing ridges with the altitudes about 3,500-4,200 $\mathrm{m}$ a.s.1. The neighboring areas of the Mongolian Altai are well known for their high seismicity (Zhalkovsky and Muchnaya 1975, Rogozhin et al 2013), and this was a reason for identifying the SE Altai as the most seismically active part of the Russian Altai. Almost the whole territory of the SE Altai is characterized by seismic intensity of 8 point according to MSK scale. High regional seismicity is evidenced by paleoruptures and numerous 


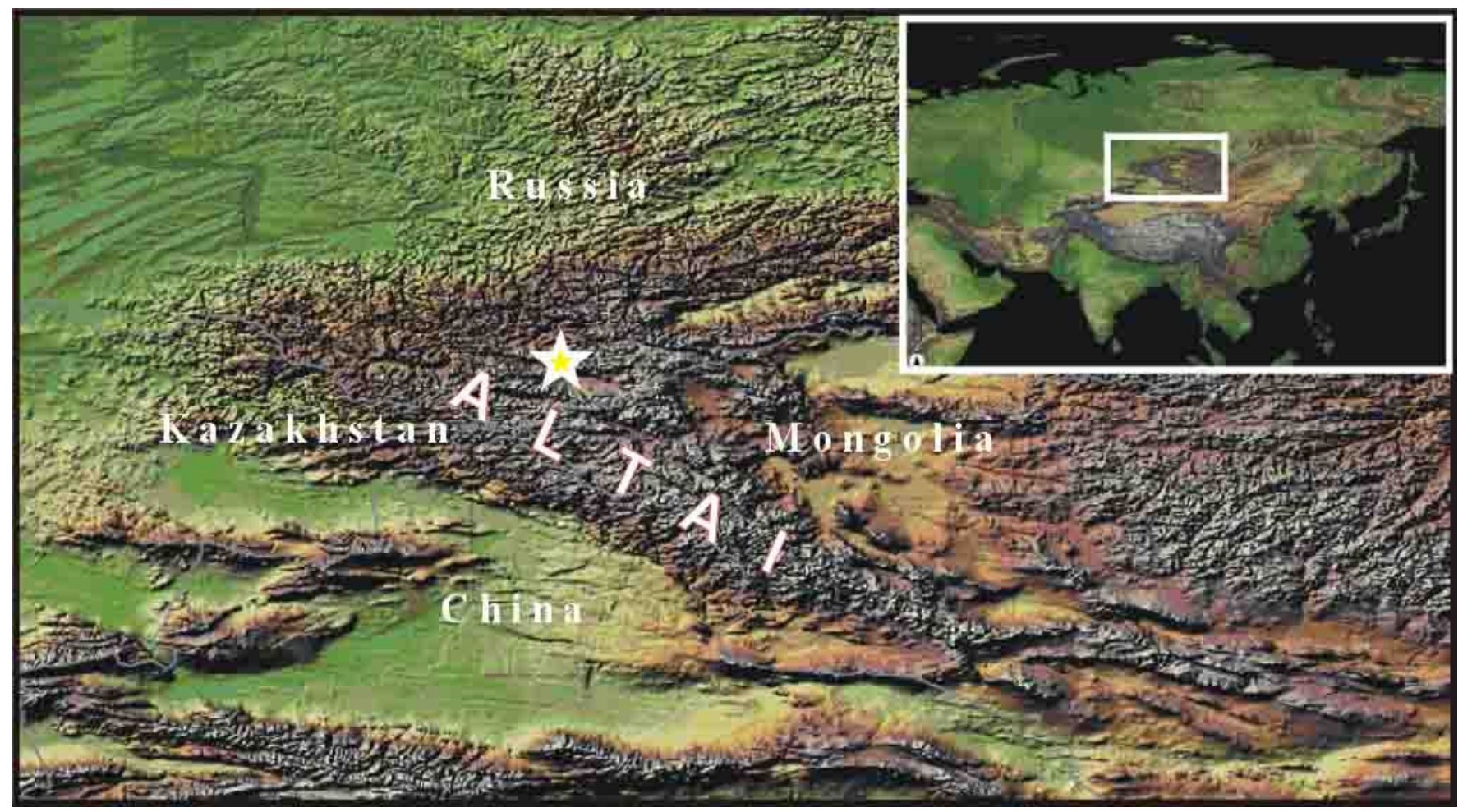

Figure 1. Altai Mountains. Star shows the location of the southeastern part of the Russian Altai

large late Pleistocene-Holocene earthquake induced landslides (Butvilovsky 1993, Rogozhin and Platonova 2002, Rogozhin et al 2007, Agatova et al 2006, 2014a). Recently this conclusion was supported by the 2003 Chuya earthquake $\left(M_{S}=7.3\right)$.

Strongly dissected topography and widely distributed unconsolidated Cenozoic sediments provide favorable conditions to produce earthquake induced landslides. Rockslides are mainly distributed within mountain ranges, framing Chuya and Kurai intermountain depressions. In contrast, the vast extent of the Neogene lacustrine and Pleistocene moraine deposits in the most active areas of the depression-range transition within the Chuya basin provides geological conditions for developing deep seated landslides.

These largest seismically induced landforms are preserved in topography for thousands of years due to extremely arid climate. The mean annual precipitation is less than $200 \mathrm{~mm}$ in the floor of intermountain depressions, significantly increasing with height. At the same time, the mean annual precipitation near the snow line decreases along the $\mathrm{W}-\mathrm{E}$ axis from 2,000 $\mathrm{mm}$ (in the western part of the Katun range) to less than $500 \mathrm{~mm}$ in the Chikhachev range near the Mongolian border (Narozny and Osipov 1999) due to decreasing of moisture transfer from the Atlantic Ocean.

Forest distribution defines low precipitation areas and aridity intensifies eastward. The stony steppe on the floor of the Kurai depression grades into taiga vegetation on the North Chuya range slopes up to 2,350-2,450 $\mathrm{m}$ a.s.1. In the western mountains flanking the Chuya depression, forests have an insular distribution, vanishing completely in the southeastern part.

Permafrost within Chuya and Kurai intermountain depressions has a patchy distribution, is located at the depth of about 3-7 m with the general thickness up to $90 \mathrm{~m}$ (Permafrost hydrogeological map 1977). Within mountain ranges unconsolidated sediments are frozen from a depth of about 0.8-1.5 m (Ostanin 2007).

The seismically active area examined in this paper includes parts of the Chuya and Kurai intermountain depressions with framing ranges and the Chagan-Uzun massif, which separates these depressions (Fig. 2). The surface of the Chagan-Uzun neotectonic block is slightly 

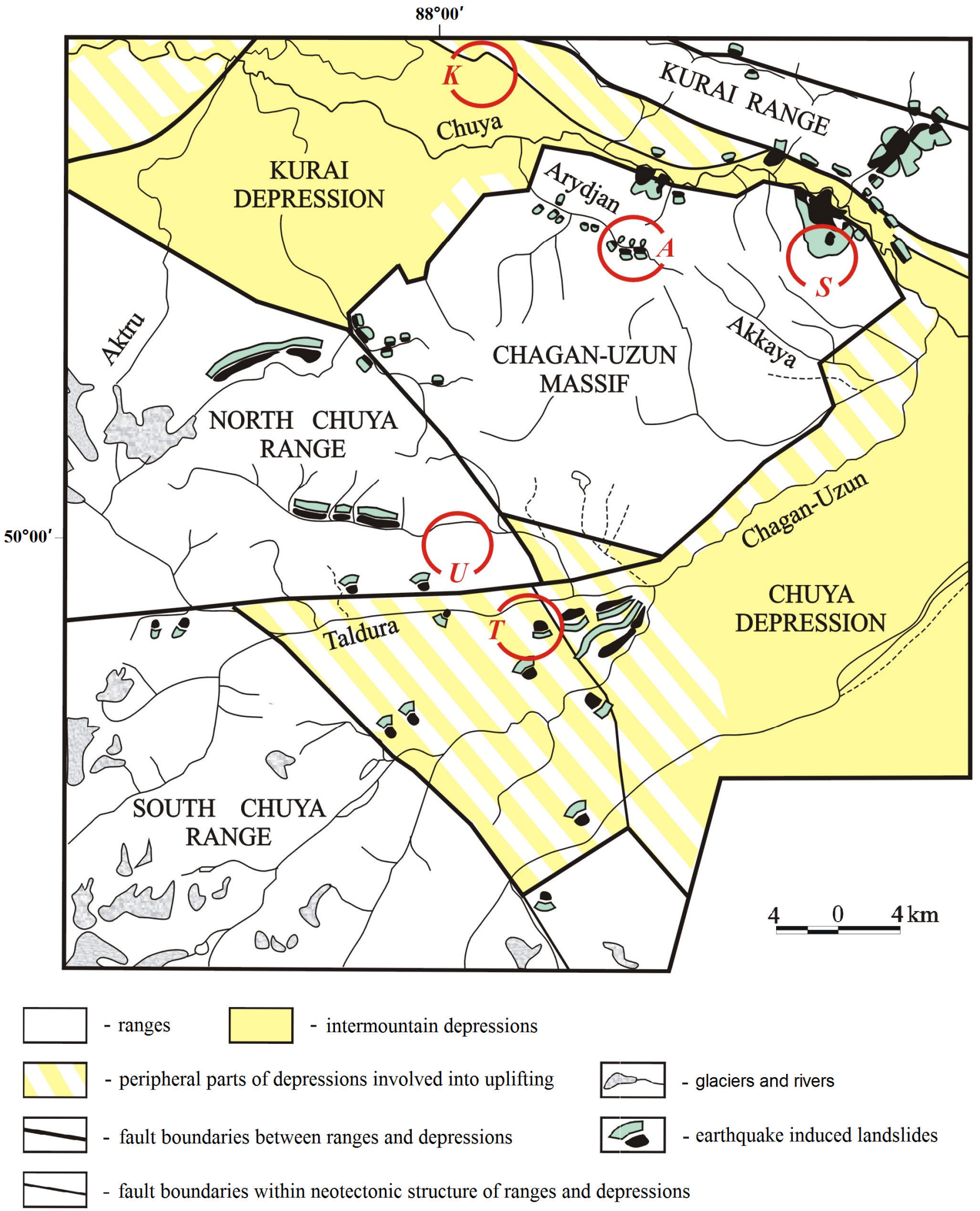

Figure 2. Sketch neotectonic map showing the locations of study sites discussed in the paper. A- Arydjan valley; K- Southern flank of the Central Kurai neotectonic foreberg; S- Sukor paleoseismic deformation; T- Taldura valley; U- Uzuk stow (Kuskunur - Taldura watershed) 
inclined eastwards to the Chuya depression with the high summits in its northern and western parts. The Sukor peak (2,926 $\mathrm{m}$ a.s.1.) is the highest one. Developing presently as a single structure the Chagan-Uzun massif together with the western part of the Chuya intermountain depression are characterized by the largest rates of vertical movement 7.84-8.00 $\mathrm{mm} \mathrm{a}^{-1}$ within the whole Chuya river basin (Rogozhin and Platonova 2002). The southern fault boundary of the Chagan-Uzun massif was reactivated during the 2003 Chuya earthquake. Epicenters of the main shock and numerous aftershocks were registered there (Emanov et al 2009). Numerous large seismically induced paleolandslides and rockfalls, that mark fault boundaries of the Chagan-Uzun massif, as well as smaller blocks of its inner structure (Fig. 2), provide evidence for its high neotectonic activity (Agatova et al 2014b).

\section{Methods}

Detailed geomorphological and paleoseismogeological investigations and process analyses were based on interpretation of aerial photographs, Landsat-TM images, topographic maps (scale of 1:25,000), and field investigations including mapping of landforms and deposits of different genesis. Our field observations of the impact of strong modern and prehistoric earthquakes reveal several criteria that were applied for interpreting the seismic origin of observed ground failures within studied area (Nepop and Agatova 2008, Agatova et al 2014b): $i$ ) the great extent of ground failures upon strongly cemented Neogene and Pleistocene permafrost sediments, as well as high concentration of numerous seismically induced landforms (both huge and small ones) within the same area; ii) location of the landslides in the most active areas at the basin-range transition, their association with the faults and fault crossings; iii) absence of correlation between location of landslides and exposition of slopes to insolation, their age and rock composition; and $i v$ ) conjunction of landslide locations with the ruptures on the watersheds and valley slopes. It should be also noted that location of giant landslides in an area of extremely dry climate rules out rainfall or snowmelt as a trigger.

Absolute age determination of ancient earthquakes is one of the key paleoseismogeological problems. The most direct dating techniques (fault scarp formation, applying scarp degradation modeling, cosmogenic surface exposure dating and analysis of scarp soils) return relatively large age uncertainties (McCalpin 2009). In this context dating landforms is typically less precise than dating sediments (Burbank and Anderson 2001, McCalpin 2009). Relatively precise indirect dating of associated deposits may also generate large age uncertainties for ancient seismic events. Thus for stratigraphic evidences of past earthquakes we consider sediments deposited shortly before an earthquake and those (newly created or with the reset properties) deposited shortly after it.

The radiocarbon method is the most exploitable and widely applicable dating technique in paleoseismogeology. It allows determining the age of soils, tree fragments and other organic materials which were deformed and/or buried during the earthquake. The application of the radiocarbon method is limited by $\sim 50 \mathrm{ka}$ (and by $\sim 75 \mathrm{ka}$ with isotopic enrichment) but some problems occurred while using this technique for dating recent (about $2 \mathrm{ka}$ ) seismic events due to high relative methodological error and presence of several "plateaus" of the calibration curve, which make age correlation with the calendar scale difficult (Wagner 1998). Thus our results of radiocarbon and dendrochronological dating of the same wood fragments from moraine deposits within SE Altai argue for the earlier ages (difference up to 300 years for the last $3 \mathrm{ka}$ ) obtained by radiocarbon analysis (Agatova et al 2014a). Such error has the same order of magnitude with the recurrence interval of strong Holocene earthquakes for the SE Altai (500 - 900 years) obtained as a result of extensive paleoseismogeological investigations including numerous radiocarbon dates (Rogozhin et al 2007, 2008). Moreover, due to the complexity and duration of the pedogenesis process, the radiocarbon age of fossil soils gives the approximate date of their formation which also complicates the timing of seismically induced landforms. 
Samples of paleosoils and peat layers (both seismically deformed and undistorted ones), charcoals, buried tree fragments were collected for radiocarbon dating in course of paleoseismogeological investigations in the epicenter zone of the 2003 Chiuya earthquake. The radiocarbon ages were measured at the Cenozoic Geochronology Center SB RAS, Novosibirsk, and at the Institute of Geography RAS, Moscow, applying standard technique (Arslanov 1987). The determination of carbon residual activity in both laboratories was done with the QUANTULUS-1220. The conventional radiocarbon ages were calibrated (2-sigma standard deviation) applying the CALIB Rev 5.0 program (Stuiver and Reimer 1993), with the IntCal09 calibration data set (Reimer et al 2009). Both calibrated (cal. BP) and radiocarbon ages are presented.

Where forest vegetation in seismically active areas is spreading, tree-ring analysis can be used as an additional or alternative approach. It has a great potential due to utmost precision of dating annual and sometimes even seasonal resolution, which is an obvious advantage in comparison with the radiocarbon analysis that only "brackets" the possible time interval of a seismic event.

Besides estimating the germination ages of trees growing on the bare surfaces of seismically triggered landslides and assessing the minimum possible age of landforms, tree ring analyses were applied for estimating the age of earthquakes that had occurred after forest regeneration on the surface of these landslides. We suppose that for trees (both dead and living ones) located near the scarps and talus fans, wood penetrating injuries could be caused by earthquake induced rock falls as exemplified during the 2003 Chuya earthquake. Developing local tree ring chronologies (TRC) or applying regional TRC gives the opportunity to date such events.

The suggested dendroseismological approach implies analysis of wood penetrating scars in the individual tree ring series for identification and dating of earthquake triggered paleorockfalls. As well as the number of such anomalies, the simultaneity of scars sustained by several trees growing on different earthquake induced landslides was taken as a criterion of their seismic origin. The accuracy of this approach was supported by data obtained from analyzing scars to trees due to rockfalls triggered by the 2003 Chuya earthquake. Growth anomalies (disturbance of the tree ring structure) were visually determined with the stereomicroscope and dated. The germination ages of trees growing on the bare surfaces of earthquake triggered landslides were also calculated. An age correction has been applied for the assessment of the colonization time gap and the time of surface stabilization.

It should be noted that besides earthquake triggered rock falls there are climatically driven ones when heavy rains or snow melting act as the main triggers. Thus determining the seismic origin of rockfalls plays a crucial role. We suggest that, similarly to the 2003 Chuya earthquake, the number and simultaneity of wood penetrating scars sustained by many trees grown in different parts of an area affected by seismic shock could be such a criterion. It should be emphasized that even after that, the dendrochronologically obtained dates of abrupt intensifications of rockfalls are just hypothesized dates of earthquakes, which should be confirmed by alternative proxy data or absolute dating techniques.

Preliminary sample preparation and dendrochronological analysis was carried out in the laboratory of natural science methods, Siberian Federal University, Krasnoyarsk. The standard procedure of building the tree ring chronologies (Shiyatov et al 2000) on Pinus Sibirica Du Tour was applied.

\section{Results}

\subsection{Unknown ground effects of the 2003 Chuya earthquake}

Our 2009 - 2011 field geological geomorphological investigations in the mountains framing the Chuya intermountain depression within different segments of the epicenter zone of the 2003 Chuya earthquake, revealed previously unknown ground effects of this recent strong seismic excitation. Detected seismic surface disturbances are seismotectonic deformations, which are sometimes accompanied by large 
funnels and ground subsidence both in rocks and unconsolidated sediments.

The most distant ground effect of the 2003 Chuya earthquake was detected at the foot of the Sajlugem range. A $1 \mathrm{~km}$ rupture of northwest direction is located $35 \mathrm{~km}$ eastward from the southeastern margin of the previously detected earthquake rupture area. This rupture went along one of the fan-like thalwegs in the inner part of the horseshoe-shaped small rock ridge in the eastern part of the Sajlugem range. In 2010 rupture opening was about $15-20 \mathrm{~cm}$. Local people reported that a crack in the swampy area appeared during the 2003 seismic excitation. Probably this fault was repeatedly reactivated during the Holocene as is evidenced by straightness of the intermittent stream thalweg, that is clearly identified in the topography.

Ruptures accompanied by large funnels ground subsidence, were detected in the central part of the pleistoseist zone beyond the area of previously documented ground effects of the 2003 Chuya earthquake, - within the ChaganUzun massif and in the Taldura river valley. In the Taldura river valley tension cracks, compression swells, and ground subsidence were discovered $9 \mathrm{~km}$ upstream from the location of the giant landslide and previously detected ruptures across the river valley (Fig. 3). The foot of the rocky slope of the valley consists of moraine deposits covered by colluvium and alluvium. System of ruptures accompanied by ground subsidence has azimuth $0-25^{\circ}$ and linked tension cracks and compression swells $-70-80^{\circ}$. The upstream part of cracks is complicated by ground subsidence, about $7 \mathrm{~m}$ in width and 10-12 $\mathrm{m}$ in length. Scarps of these subsidences are up to 0.3-0.8 m. Deformation features indicate displacement along dextral strike slip fault. Paleosoils for radiocarbon analysis were collected from the scarp of the downslope ground subsidence.

Most impressive previously unknown ground effects were discovered within the Chagan-Uzun massif. A large funnel (6-7 $\mathrm{m}$ in depth and about $30 \mathrm{~m}$ in diameter (Fig. 4)) was formed in the Riphean-Vendian marbleized limestones at the bottom of a short through valley, stretched in latitudinal direction and connecting Yeldyskel

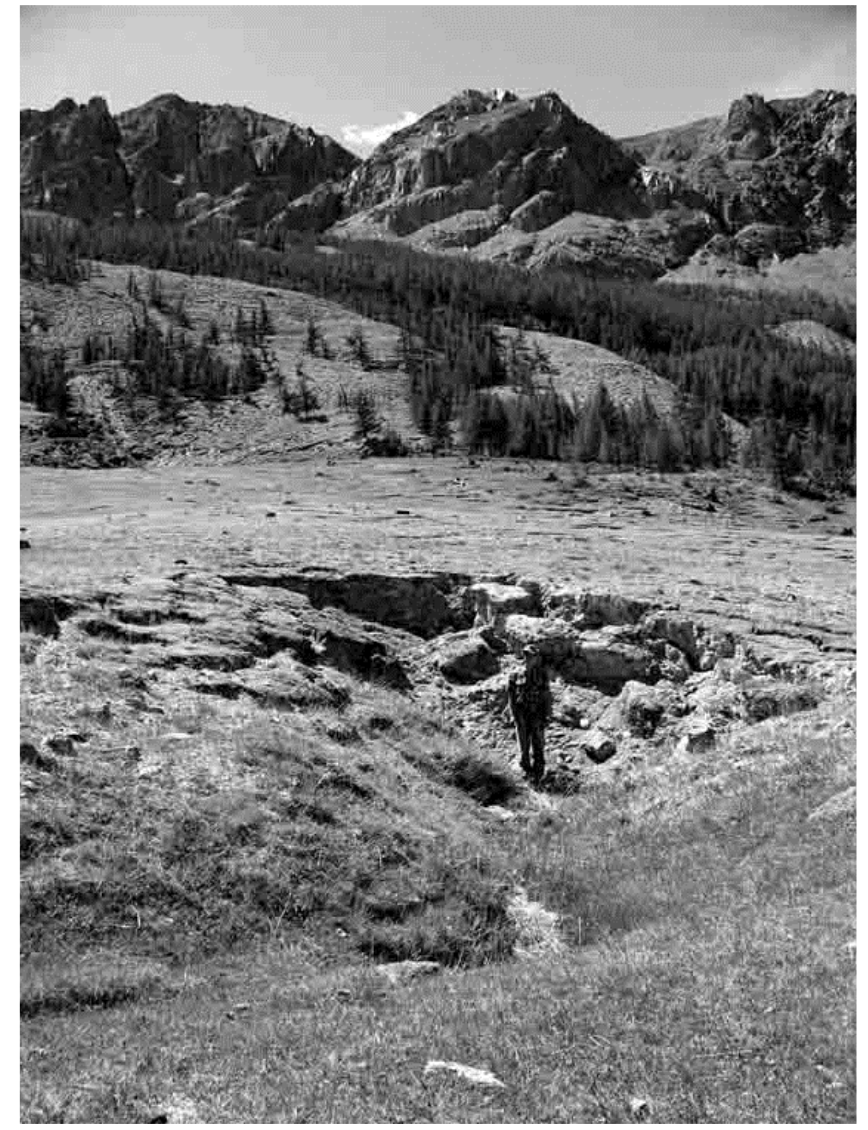

Figure 3. One of previously not documented tension gashes alternating with the pressure ridges (in the foreground on the left) in Taldura river valley. The pressure ridges are oriented oblique to the main rupture zone of the 2003 Chuya earthquake. Person in the center of the tension gash is $1.9 \mathrm{~m}$ tall

area and Kara-Airy valley. Crushed and ferruginous zones on the slopes of this funnel indicate repeated reactivations of the same sublatitudinal faults that are connected with the spreading of the massif in this area. They give evidence for seismic origin of this valley as well the Kara-Airy valley a micrograben of seismic origin was detected. This micrograben transforms into a thrust fault with the height of the scarp of about $1.5-2 \mathrm{~m}$, that was most likely produced by as of some parallel short and wide valleys on the right slope of the Kara-Airy valley. In an extension of this valley on the opposite slope of repeated past earthquakes with the same kinematic conditions. This system of seismic deformation is terminated by two funnels ground subsidence in unconsolidated coarse deposits. The largest among them is about $7 \mathrm{~m}$ in diameter and $5 \mathrm{~m}$ in depth (Fig. 5). High ground 


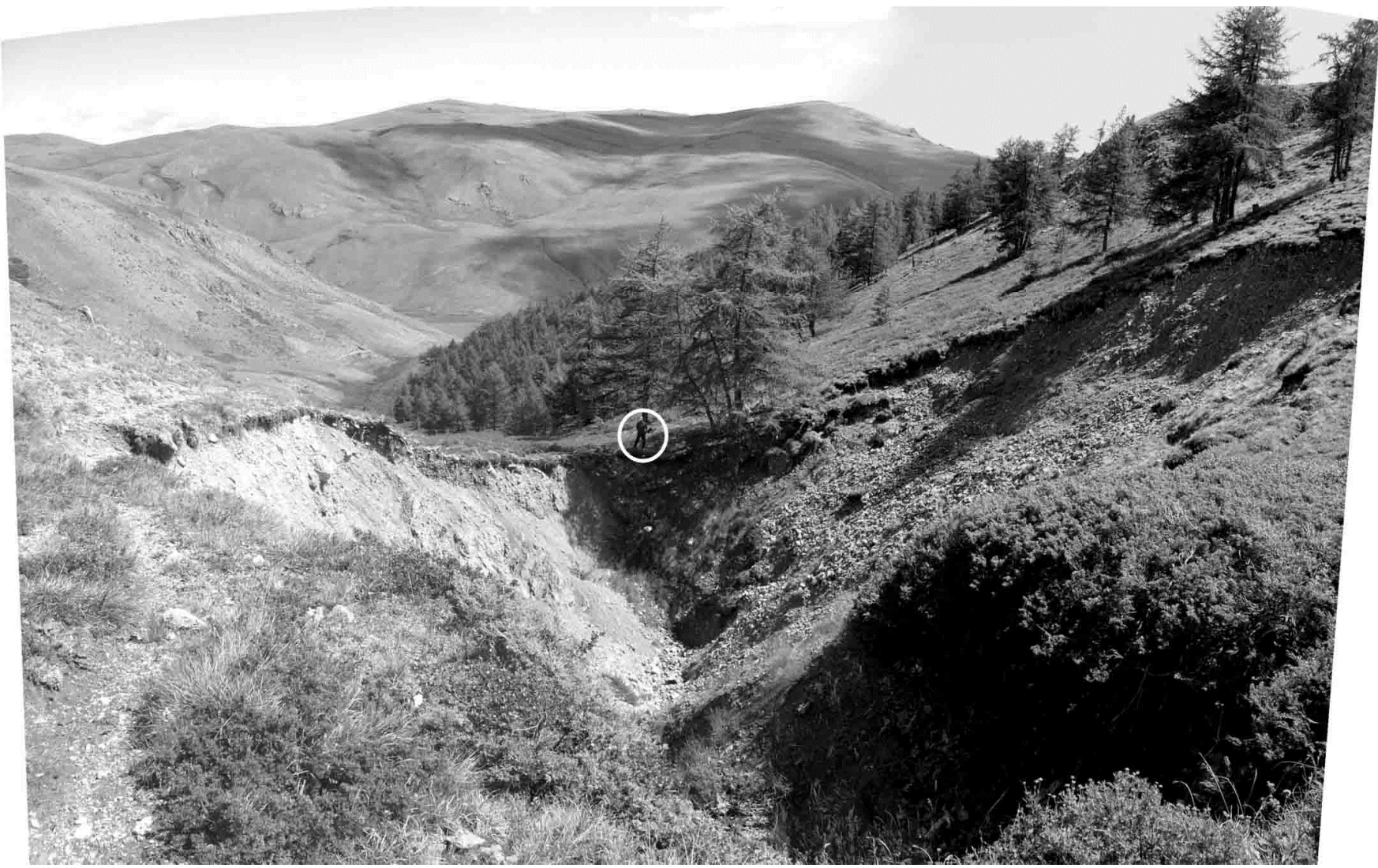

Figure 4. Ground subsidence in Riphean-Vendian marbleized limestones in the central part of the Chagan-Uzun massif. Person in a circle is $1.8 \mathrm{~m}$ tall

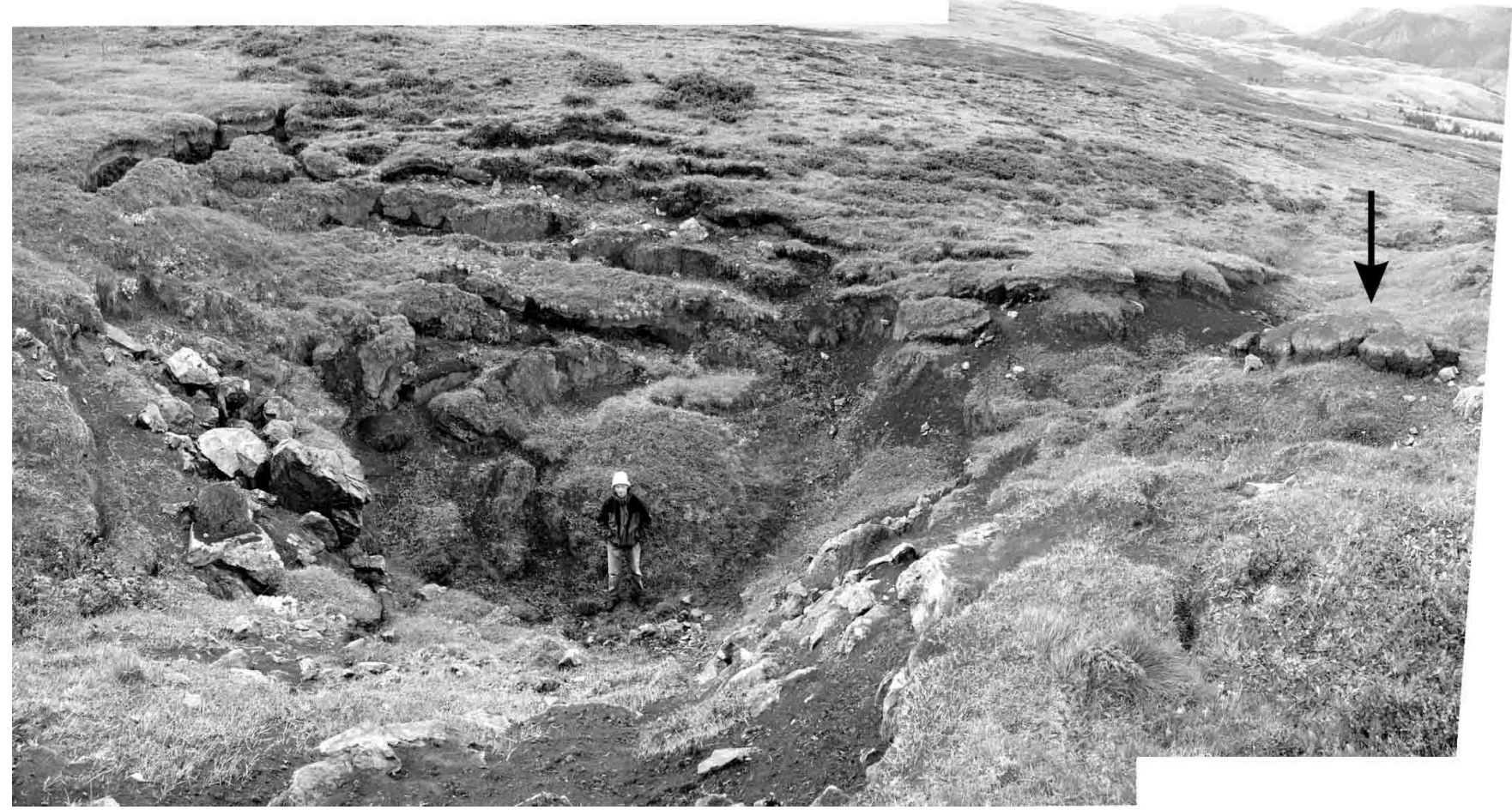

Figure 5. One of the funnels in unconsolidated sediments within rupture area (central part of the Chagan-Uzun massif). Person is $1.8 \mathrm{~m}$ tall. Arrow shows detached and thrown piece of grass covered peat sheet 
accelerations during seismic excitation are evidenced by a detached and upside down sodded peat sheet about $1.5 \mathrm{~m}$ in length and $0.3 \mathrm{~m}$ thick, that was thrown to the opposite slope of the funnel. Seismic deformations on the eastern part of the Chagan-Uzun massif $17 \mathrm{~km}$ from previously documented surface disturbances were generated by the 2003 Chuya earthquake.

Seismic deformations of coarse deposits were detected within multievent Sukor seismogravitational paleodeformation, the largest such landform in the SE Altai. The late Pleistocene age of its formation was suggested by (Butvilovsky 1993). We classify this landform as giant rockslide. It is evidenced by circular shaped contours of valleys that mark the main scarp of the Sukor paleodeformation in the northeastern part of the Chagan-Uzun massif. The main factors that control the volume of displaced strata are $i$ ) the altitude of the Sukor summit is the highest of the whole massif, $i$ ) the location of the Sukor paleodeformation on the block boundary and associated abrupt elevation changes (up to 1000 $\mathrm{m})$ and iii) rock composition is a serpentinized ultramafic that provides glide planes. The foot of the main scarp of this deformation and part of the accumulative body associated with ancient landsliding events are covered by rock glaciers. In 2003 seismogravitational ruptures within these rock glaciers caused splitting of some tree trunks. Ruptures of NW-SE direction were documented on the surface of one relatively young accumulative landslide body in the eastern part of the Sukor paleodeformation.

\subsection{Radiocarbon dating of ground effects of strong prehistoric earthquakes within the SE Altai}

All newly obtained radiocarbon dates and their paleoseismogeological interpretation are presented in Table 1. Our paleoseismogeological researches were focused mainly at the epicenter zone of the 2003 Chuya earthquake. Newly arisen and renewed scarps and ruptures gave a unique opportunity to study previously unknown evidences of strong prehistoric earthquakes. A lot of suitable material was collected in the Taldura river valley where the giant landslide was generated (Fig. 6).
This is the largest landslide triggered by the 2003 Chuya earthquake. It is located $5 \mathrm{~km}$ upstream the confluence of the Chagan and Taldura rivers $(7 \mathrm{~km}$ far from the destroyed Beltir local settlement). The landslide was generated on the stable, grass and forest covered right valley slope. The main scarp of about $100 \mathrm{~m}$ was developed along one of the ruptures. A system of earthquake ruptures crosses the Chagan-Taldura watershed at this place, and the landslide is located directly in the area of primary seismotectonic deformations of the 2003 Chuya earthquake. The accumulative landslide body is about $0.9 \times 0.6 \mathrm{~km}$. The brow of the main scarp is located at 2,300-2,320 $\mathrm{m}$ a.s.1. The short distance run and block structure of this landslide could be explained by gentle slopes, relatively low height in this part of the valley, and by widely distributed permafrost, which could be clearly identified from the depth of about $2 \mathrm{~m}$ (Agatova et al 2004). Slope strata were moved not only downslope but also downstream of the valley, which indicate the right-shear displacement along the strike-slip fault. Landsliding was accompanied by rotation of blocks. Generally the landslide surface has the structure of "broken plate". The front, back and upslope parts of the landslide are the most destroyed. They have separate blocks and ramparts up to $30-50 \mathrm{~m}$ in height. The downslope side is contoured by a system of ruptures up to $6 \mathrm{~m}$ in width. The center part slipped downslope, subsided but preserved primary topography and even fragments of dirt road. In the back part landslide is broken into numerous differently inclined blocks. Surviving trees on their surface ("drunken forest"), now already partially dead, allow visual assessment of the grand scale of this natural phenomenon. Between the main scarp and the landslide accumulative body, as well as between separate blocks in its back part, numerous lakes were developed in 2004 as a result of permafrost degradation. Already today most of them do not exist. The only evidences of these geomorphic processes are sandy-clay sediments formed by redeposition of the Neogene lacustrine and moraine deposits.

It should be also noted that above this landslide in the axial part of the watershed there 
are two landslides of about $250 \times 350$ and $350 \times$ $400 \mathrm{~m}$ adjacent to each other. Downstream the Chagan river there are some significantly larger giant paleolandslides triggered by prehistoric earthquakes.

In 2011 numerous evidences of past earthquakes were detected when studying the back and upstream parts of the accumulative landslide body, namely cut paleosoils and peat layers, redeposited fragments of charcoals resulting in inversion of radiocarbon dates in outcrops, and seismic convolutions in sediments of an ancient lake, developed in the back area of the earthquake triggered landslide in the same manner as modern ones.

Radiocarbon dating of seismically deformed fossil soil and buried peat layer in the proximal part of 2003 landslide (Fig. 7, Location 1, Fig. 6) gave 2,234 \pm 119 cal. BP (IGAN 4090) and $848 \pm 111$ cal. BP (IGAN 4105). The age of

Table 1 New radiocarbon dates used for estimating the recurrence interval of strong prehistoric earthquakes in the SE Altai

\begin{tabular}{|c|c|c|c|c|}
\hline $\begin{array}{l}\text { Sample } \\
\text { lab. cod }\end{array}$ & $\begin{array}{l}\text { Location } \\
\text { Fig. } 2\end{array}$ & Sample type & ${ }^{14} \mathrm{C}$ age* & Interpretation \\
\hline $\begin{array}{c}\text { IGAN } \\
4090\end{array}$ & $\mathrm{~T}$ & $\begin{array}{l}\text { seismically cut fossil soil } \\
\text { exhumed in rupture of the } \\
2003 \text { Chuya earthquake }\end{array}$ & $\begin{array}{c}\text { HA } \\
2240 \pm 60 \\
(2234 \pm 119)\end{array}$ & $\begin{array}{l}\text { low possible date of strong } \\
\text { earthquake that cut and buried } \\
\text { soil layer }\end{array}$ \\
\hline $\begin{array}{l}\text { IGAN } \\
4092\end{array}$ & $\mathrm{~T}$ & $\begin{array}{l}\text { char coal from seismically } \\
\text { deformed fossil soil }\end{array}$ & $\begin{array}{c}\mathrm{CC} \\
1460 \pm 70 \\
(1400 \pm 120) \\
\end{array}$ & $\begin{array}{l}\text { low possible date of strong } \\
\text { earthquake that deformed and } \\
\text { buried soil layer }\end{array}$ \\
\hline $\begin{array}{l}\text { IGAN } \\
4103\end{array}$ & $\mathrm{~T}$ & $\begin{array}{l}\text { paleosoils overlaid by } \\
\text { colluvium sediments }\end{array}$ & $\begin{array}{c}\text { HA } \\
510 \pm 60 \\
(559 \pm 94) \\
\end{array}$ & $\begin{array}{l}\text { period of tectonic repose and } \\
\text { soil formation at the foot of the } \\
\text { steep slope }\end{array}$ \\
\hline $\begin{array}{c}\text { IGAN } \\
4104\end{array}$ & $\mathrm{~T}$ & $\begin{array}{l}\text { paleosoils overlaid by } \\
\text { colluvium sediments }\end{array}$ & $\begin{array}{c}\text { HA } \\
600 \pm 60 \\
(596 \pm 70)\end{array}$ & $\begin{array}{l}\text { period of tectonic repose and } \\
\text { soil formation at the foot of the } \\
\text { steep slope }\end{array}$ \\
\hline $\begin{array}{l}\text { IGAN } \\
4105\end{array}$ & $\mathrm{~T}$ & $\begin{array}{l}\text { seismically cut fossil soil } \\
\text { exhumed in rupture of the } \\
2003 \text { Chuya earthquake }\end{array}$ & $\begin{array}{c}\text { HA } \\
950 \pm 60 \\
(848 \pm 111) \\
\end{array}$ & $\begin{array}{l}\text { low possible date of strong } \\
\text { earthquake that cut and buried } \\
\text { soil layer }\end{array}$ \\
\hline $\begin{array}{c}\text { IGAN } \\
4106\end{array}$ & $\mathrm{~T}$ & $\begin{array}{l}\text { paleosoils overlaid by } \\
\text { colluvium sediments }\end{array}$ & $\begin{array}{c}\text { HA } \\
710 \pm 70 \\
(654 \pm 110) \\
\end{array}$ & $\begin{array}{l}\text { period of tectonic repose and } \\
\text { soil formation at the foot of the } \\
\text { steep slope }\end{array}$ \\
\hline $\begin{array}{l}\text { SOAN } \\
8416\end{array}$ & $\mathrm{~T}$ & $\begin{array}{l}\text { seismically cut peat layer } \\
\text { covered lacustrine sediments } \\
\text { with seismic convolutions }\end{array}$ & $\begin{array}{c}\text { HA } \\
2040 \pm 55 \\
(2011 \pm 129) \\
\end{array}$ & $\begin{array}{l}\text { low possible date of } \\
\text { earthquake that formed } \\
\text { convolution structures }\end{array}$ \\
\hline $\begin{array}{l}\text { SOAN } \\
8417\end{array}$ & $\mathrm{~T}$ & charcoal from paleosoil layer & $\begin{array}{c}\mathrm{CC} \\
2755 \pm 40 \\
(2859 \pm 88)\end{array}$ & $\begin{array}{l}\text { low possible date of strong } \\
\text { earthquake that deformed and } \\
\text { buried soil layer }\end{array}$ \\
\hline $\begin{array}{l}\text { SOAN } \\
8418\end{array}$ & $\mathrm{~T}$ & $\begin{array}{l}\text { fossil soil with charcoal } \\
\text { overlaid by colluvium } \\
\text { sediments }\end{array}$ & $\begin{array}{c}\text { HA } \\
2535 \pm 40 \\
(2618 \pm 131) \\
\end{array}$ & $\begin{array}{l}\text { period of tectonic repose and } \\
\text { soil formation }\end{array}$ \\
\hline $\begin{array}{l}\text { SOAN } \\
8419\end{array}$ & $\mathrm{~T}$ & $\begin{array}{l}\text { fossil soil with charcoal } \\
\text { overlaid by colluvium } \\
\text { sediments }\end{array}$ & $\begin{array}{c}\text { HA } \\
3335 \pm 40 \\
(3577 \pm 109) \\
\end{array}$ & $\begin{array}{l}\text { period of tectonic repose and } \\
\text { soil formation }\end{array}$ \\
\hline $\begin{array}{l}\text { SOAN } \\
8425\end{array}$ & K & $\begin{array}{l}\text { wood fragment from } \\
\text { humified loam layer overlaid } \\
\text { by colluvium sediments }\end{array}$ & $\begin{array}{c}\mathrm{W} \\
845 \pm 35 \\
(792 \pm 107)\end{array}$ & $\begin{array}{l}\text { stabilization period of the } \\
\text { alluvial-colluvial fan at the } \\
\text { foot of the rocky slope }\end{array}$ \\
\hline
\end{tabular}




\begin{tabular}{|c|c|c|c|c|}
\hline $\begin{array}{c}\text { SOAN } \\
8549\end{array}$ & $\mathrm{~K}$ & $\begin{array}{l}\text { humified loam layer overlaid } \\
\text { by colluvium sediments }\end{array}$ & $\begin{array}{c}\text { HA } \\
3275 \pm 80 \\
(3525 \pm 168)\end{array}$ & $\begin{array}{l}\text { stabilization period of the } \\
\text { alluvial-colluvial fan at the } \\
\text { foot of the rocky slope }\end{array}$ \\
\hline $\begin{array}{l}\text { SOAN } \\
8658\end{array}$ & $\mathrm{~T}$ & $\begin{array}{l}\text { wood fragments from fossil } \\
\text { peat layer in the proximal } \\
\text { part of the giant landslide } \\
\text { triggered by the } 2003 \text { Chuya } \\
\text { earthquake }\end{array}$ & $\begin{array}{c}\mathrm{W} \\
650 \pm 65 \\
(611 \pm 78)\end{array}$ & $\begin{array}{l}\text { upper possible date of strong } \\
\text { earthquake that coursed peat } \\
\text { bog formation }\end{array}$ \\
\hline $\begin{array}{c}\text { SOAN } \\
8659\end{array}$ & $\mathrm{~T}$ & $\begin{array}{l}\text { contemporary soil } \\
\text { overlapping seismically cut } \\
\text { paleosoils }\end{array}$ & $\begin{array}{c}\text { HA } \\
250 \pm 30 \\
(297 \pm 27) \\
\end{array}$ & $\begin{array}{l}\text { upper possible date of strong } \\
\text { paleoearthquake }\end{array}$ \\
\hline $\begin{array}{l}\text { SOAN } \\
8663\end{array}$ & $\mathrm{~T}$ & $\begin{array}{l}\text { seismically cut fossil soil } \\
\text { with charcoal }\end{array}$ & $\begin{array}{c}\text { HA } \\
2380 \pm 65 \\
(2463 \pm 249)\end{array}$ & $\begin{array}{l}\text { low possible date of strong } \\
\text { earthquake that cut and buried } \\
\text { soil layer }\end{array}$ \\
\hline $\begin{array}{l}\text { SOAN } \\
8664\end{array}$ & $\mathrm{~T}$ & $\begin{array}{l}\text { fossil peat layer with } \\
\text { charcoal in the proximal part } \\
\text { of the giant landslide } \\
\text { triggered by the } 2003 \text { Chuya } \\
\text { earthquake }\end{array}$ & $\begin{array}{c}\text { HA } \\
1035 \pm 45 \\
(929 \pm 129)\end{array}$ & $\begin{array}{l}\text { upper possible date of strong } \\
\text { earthquake that coursed peat } \\
\text { bog formation }\end{array}$ \\
\hline $\begin{array}{l}\text { SOAN } \\
8665\end{array}$ & $\mathrm{~T}$ & $\begin{array}{l}\text { seismically cut fossil soil } \\
\text { with charcoal }\end{array}$ & $\begin{array}{c}\text { HA } \\
2295 \pm 40 \\
(2257 \pm 100)\end{array}$ & $\begin{array}{l}\text { low possible date of strong } \\
\text { earthquake that cut and buried } \\
\text { soil layer }\end{array}$ \\
\hline $\begin{array}{l}\text { SOAN } \\
8666\end{array}$ & $\mathrm{~T}$ & $\begin{array}{l}\text { wood fragments from fossil } \\
\text { soil layer }\end{array}$ & $\begin{array}{c}\mathrm{W} \\
1935 \pm 35 \\
(1902 \pm 84)\end{array}$ & $\begin{array}{l}\text { low possible date of strong } \\
\text { earthquake that deformed and } \\
\text { buried soil layer }\end{array}$ \\
\hline $\begin{array}{l}\text { SOAN } \\
8667\end{array}$ & $\mathrm{~T}$ & $\begin{array}{l}\text { wood fragments from fossil } \\
\text { soil layer }\end{array}$ & $\begin{array}{c}\mathrm{W} \\
2390 \pm 65 \\
(2520 \pm 192)\end{array}$ & $\begin{array}{l}\text { low possible date of strong } \\
\text { earthquake that deformed and } \\
\text { buried soil layer }\end{array}$ \\
\hline $\begin{array}{l}\text { SOAN } \\
8668\end{array}$ & $\mathrm{~T}$ & $\begin{array}{l}\text { wood fragments from fossil } \\
\text { soil layer }\end{array}$ & $\begin{array}{c}\mathrm{W} \\
2490 \pm 35 \\
(2547 \pm 181) \\
\end{array}$ & $\begin{array}{l}\text { low possible date of strong } \\
\text { earthquake that deformed and } \\
\text { buried soil layer }\end{array}$ \\
\hline $\begin{array}{l}\text { SOAN } \\
8669\end{array}$ & $\mathrm{~T}$ & fossil soil with charcoal & $\begin{array}{c}\text { HA } \\
2540 \pm 50 \\
(2567 \pm 191)\end{array}$ & $\begin{array}{l}\text { low possible date of strong } \\
\text { earthquake that interrupt soil } \\
\text { formation }\end{array}$ \\
\hline $\begin{array}{l}\text { SOAN } \\
8670\end{array}$ & $\mathrm{~T}$ & charcoal in sandy loams & $\begin{array}{c}\mathrm{CC} \\
3785 \pm 45 \\
(4184 \pm 197)\end{array}$ & $\begin{array}{l}\text { intensification of slope } \\
\text { processes }\end{array}$ \\
\hline $\begin{array}{c}\text { SOAN } \\
8671\end{array}$ & $\mathrm{~T}$ & $\begin{array}{l}\text { charcoal in lacustrine } \\
\text { sediments }\end{array}$ & $\begin{array}{c}\mathrm{CC} \\
3765 \pm 45 \\
(4133 \pm 151) \\
\end{array}$ & $\begin{array}{l}\text { upper possible date of strong } \\
\text { earthquake that coursed lake } \\
\text { formation }\end{array}$ \\
\hline $\begin{array}{l}\text { SOAN } \\
8672\end{array}$ & $\mathrm{~T}$ & buried peat & $\begin{array}{c}\text { HA } \\
3590 \pm 45 \\
(3899 \pm 174)\end{array}$ & $\begin{array}{l}\text { upper possible date of strong } \\
\text { earthquake that coursed peat } \\
\text { bog formation }\end{array}$ \\
\hline $\begin{array}{l}\text { SOAN } \\
8673\end{array}$ & $\mathrm{~T}$ & $\begin{array}{l}\text { buried peat layer in the } \\
\text { proximal part of the giant } \\
\text { landslide triggered by the } \\
2003 \text { Chuya earthquake }\end{array}$ & $\begin{array}{c}\text { HA } \\
770 \pm 40 \\
(713 \pm 52)\end{array}$ & $\begin{array}{l}\text { upper possible date of strong } \\
\text { earthquake that coursed peat } \\
\text { bog formation }\end{array}$ \\
\hline
\end{tabular}

* Radiocarbon analysis was made on CC - charcoal, HA- humic acid, W - wood. Calibrated ages are given in brackets at the $2 \sigma$ level 


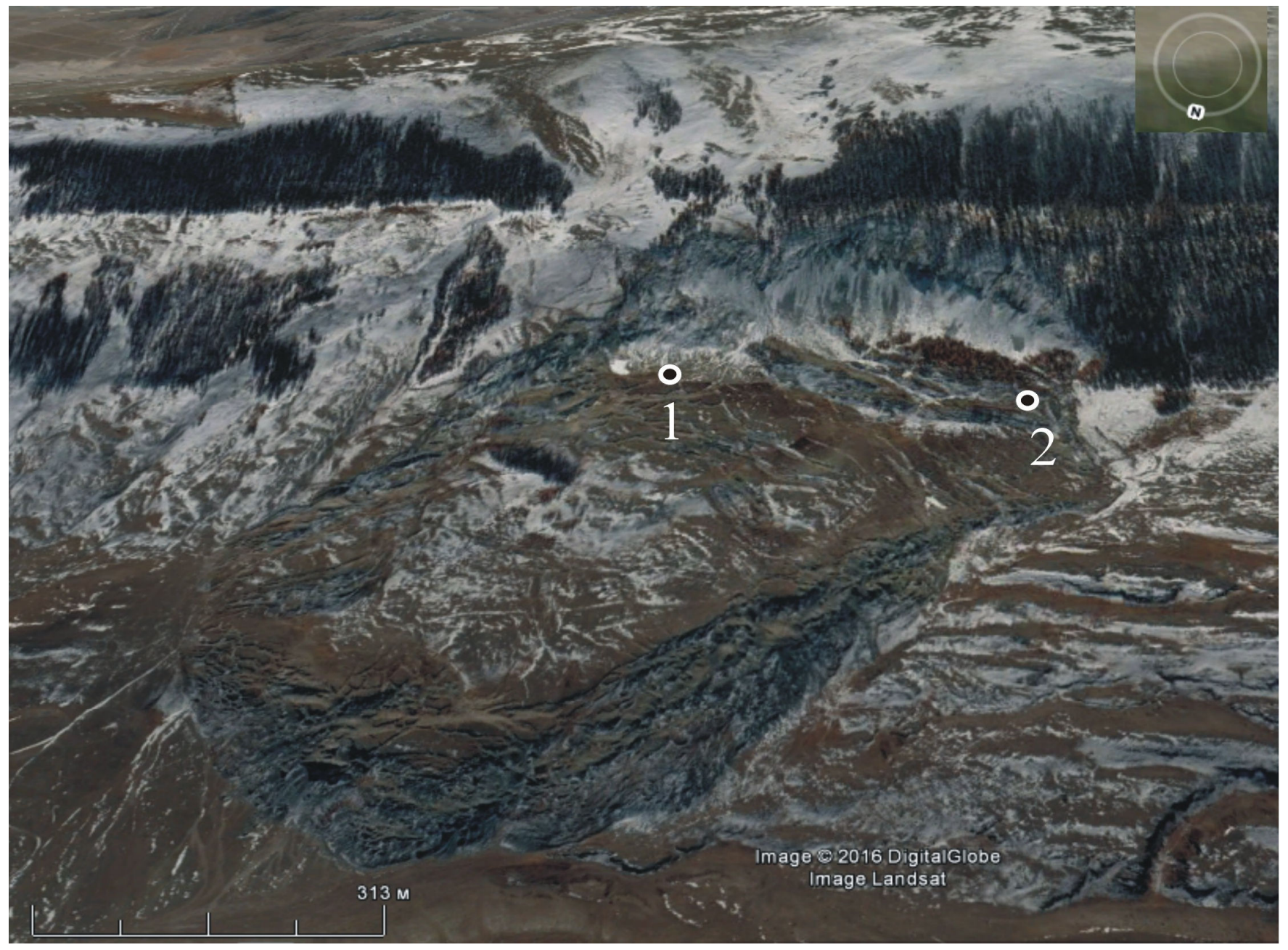

Figure 6. The largest landslide triggered by the 2003 Chuya earthquake in Taldura river valley. Numbers show the location of studied sections

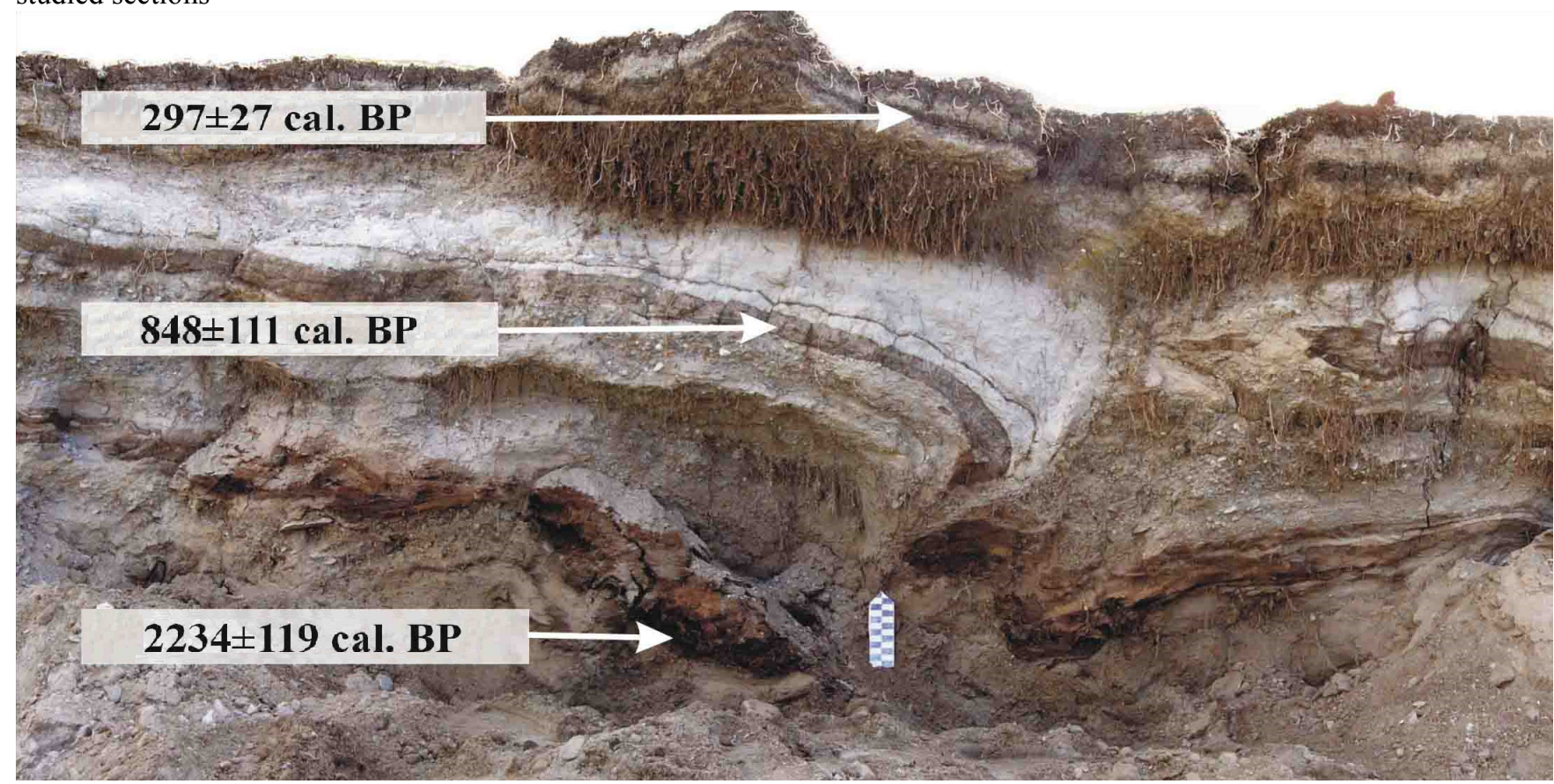

Figure 7. Newly arisen outcrop in one of the scarps of the giant landslide triggered by the 2003 Chuya earthquake in the Taldura valley (location 1, Fig. 6) 


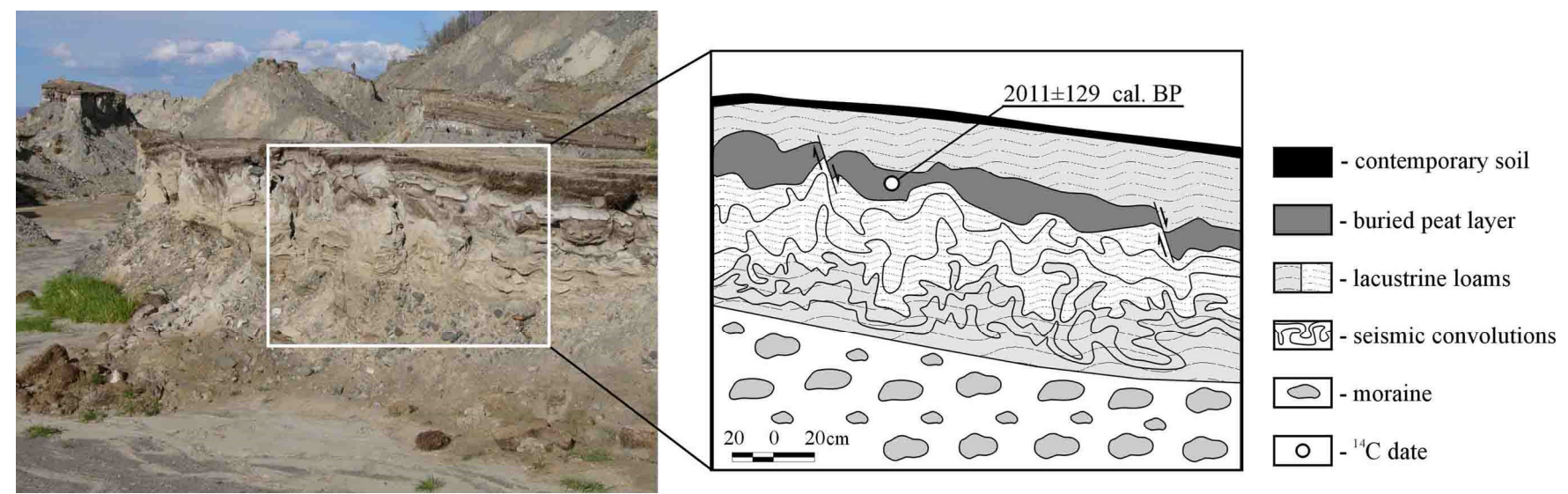

Figure 8. Section of lacustrine sediments with the peat layer in the Taldura valley (location 1, Fig. 6)

undistorted fossil soil covering them is $297 \pm 27$ cal. BP (SOAN 8659). Therefore it could be stated that the earthquake, that took place between $848 \pm 111$ and $297 \pm 27$ cal. BP, had already caused deformation of slope strata displaced during the 2003 seismic event.

Radiocarbon dates of buried peat layers as well as a fragment of a tree trunk in lacustrine deposits gave the upper possible age of earthquakes that caused peat bog or lake formation in the proximal part of paleolandslide that previously existed at the same place were $(611 \pm 78, \quad 713 \pm 52, \quad 929 \pm 129, \quad 3,899 \pm 174$, $4,133 \pm 151$ cal. BP (SOAN 8658, 8673, 8664, 8672, 8671)). In section (Fig. 8, Location 1, Fig. 6) the seismically cut buried peat layer covers lacustrine sediments with seismic convolutions and underlies deposits of a younger lake. Marking the period of tectonic respite and peat bog formation the age of peat $(2,011 \pm 129$ cal. BP (SOAN 8416)) also indicates a time period between two possible prehistoric seismic events. One of these developed seismic convolutions and another caused cutting of a peat layer and lake formation.

Deposits exhumed in an outcrop in one of the scarps of the giant landslide triggered by the 2003 Chuya earthquake in the Taldura valley indicate a complicated slope sedimentation pattern. A section of redeposited slope material with broken and deformed thin soil layers stuffed with charcoal and charred tree fragments overlies brownish sandy loams above moraines and a layer of buried soil of 2,567 $\pm 191 \mathrm{cal}$. BP (SOAN 8669) (Location 2, Fig. 6). Radiocarbon dating of organic material from deformed layers of fossil soils gives evidence for at least two periods (about 1,400 and 2,600 cal. BP) of abrupt intensification of slope activity, which can be related to seismic excitations. Slope failures induced by a seismic event occurred about 1,400 cal. BP, buried trees of the same age with significantly older deposits containing the older charcoal and tree fragments (SOAN 8417, 8666, 8667 ) including trees killed by an earthquake that occurred about 2,600 cal. BP (SOAN 8668). Deformation and burying of paleosoils from another outcrop in the same part of the landslide (2,618 $\pm 131,3,577 \pm 109$ cal. BP (SOAN 8418, 8419)) support the idea that an earthquake occurred about 2,600 cal. BP and allows suggesting presence of another older seismic event about 3,500 cal. BP.

Fossil soils buried by colluvium at the foot of the steep slopes mark periods of tectonic quiescence and soil formation that were altered by intensive slope mass movements. Ages of these fossil soils could be also interpreted as the upper possible ages of earthquakes that triggered intensive displacement of slope strata. Several such estimates were revealed from radiocarbon dates of fossil soils in in outcrops in the upper part of the Taldura valley $(559 \pm 94,596 \pm 70$, $654 \pm 110$ cal. BP (IGAN 4103, 4104, 4106)).

Radiocarbon dates of fossil soils buried by talus fans at the foot of the Kurai range in Kurai intermountain depression (792 $\pm 107,3,525 \pm 168$ cal. BP (SOAN 8425, 8549)) also give the upper ages of possible past seismic events that caused soil burial. 


\subsection{Applying dendroseismological approach in course of paleoseismogeological investigations within the SE Altai}

Dendroseismological approach was tested on the two largest landslides (located at 2,250-2,200 and 2,170-2,130 $\mathrm{m}$ a.s.1.) from complex of the earthquake triggered landslides in the Arydjan valley, in the northern part of the Chagan-Uzun massif. High concentration of numerous seismically induced landforms (both large and small ones) within the same area; absence of correlation between location of landslides and exposure of slopes to insolation, their age and rock composition; correspondence of landslides to fault boundaries of landforms and fault crossings; conjunction of landslide locations with the ruptures on the watersheds and valley slopes argue for the seismic origin of the studied landslides.

Distribution of forest vegetation on these landslides near the upper timber limit including well preserved old dead trees encouraged the study. Siberian pine (Pinus sibirica Du Tour) is the main forest forming tree species at this altitude in the Arydjan valley. Single trees settled on the surface of taluses and rock-streams leaned over on landslides. The upper timber limit in this part of the SE Altai extends slightly above the accumulative landslide bodies but the scarp of the upstream landslide with the height of about 150$170 \mathrm{~m}$ is not settled by trees due to slope steepness and active taluses. More gentle main scarp of the older downslope landslide is settled by single trees.

Sampling was carried out with the main goal of building the longest possible TRC and obtaining a representative sample collection of wood penetrating injuries. Samples were taken from trees (both living and dead ones) located on the surfaces of the talus fans and landslides near the scarps or most active talus gullies. Trees with scars on the upslope facing and lateral sides of the trunks (affected by frontal and tangential impact of falling stones) were selected among the standing ones. Cores and wedge shaped samples were taken from living trees and discs - from dead ones. In order to provide reliable dating additional discs were collected from the unscarred parts of tree trunks as well as cores from undamaged living trees.

As a result of the preceding geomorphological study, collecting and culling the samples, altogether 61 discs (49 from the downslope landslide and 12 from the upslope one) from the 36 dead trees (30 from the downslope landslide and 6 from the upslope one) with the scarred traces were analyzed. Tree ring width measurements of several samples collected from the same tree were brought into a generalized series. Thus finally every tree was represented by a single TRC. To provide the dendrochronological dating of wood penetrating scars the local 1,154-years (AD 856 till 2009) TRC on Pinus sibirica Du Tour was constructed (Agatova et al 2014b).

The year of birth of the oldest examined trees which colonized the surface of the talus fans covering landslide bodies is AD 1069 and AD 856 for the upslope and downslope landslides respectively. In order to estimate the time of creation of earthquake triggered landslides in addition to the germination ages of trees growing on their surfaces, the colonization time gap (no more than 50-100 years as it was evidenced by germination ages of trees that settled the LIA moraines in the SE Altai) and the formation time of talus fans covered landslide bodies, as well as surface stabilization period, should be taken into consideration. Due to these reasons the applied age correction can reach two centuries. Thus, it could be asserted that by AD 600-700 the studied seismically triggered landslides in the Arydjan valley had existed. The currently available data do not allow clear distinguishing of the time of landslides formation.

From 120 traumatic injuries of tree rings, three and more coincide into the years 1316, 1422, 1532 and 2003 (Agatova et al 2014b). At the same time numerous wood penetrating scars dated by AD 1532 are indicated for trees grown at both landslides and are displayed at various heights of tree trunks. This fact can imply a high magnitude of a medieval seismic event or/and its nearby epicenter location. Same patterns of wood penetrating scars caused by rockfalls, triggered by the 2003 Chuya earthquake with its epicenter located on the southern border of the ChaganUzun massif, allow us to assume that a strong 
earthquake struck SE Altai in 1532. Most likely, as in 2003, in 1532 the fault boundaries of the Chagan-Uzun massif were reactivated.

\section{Discussion}

\subsection{Studying the pleistoseist zone of the 2003 Chuya earthquake}

The 2003 Chuya earthquake was caused by reactivating the southern boundary of the Chagan-Uzun massif, which separates Kurai and Chuya intermountain depressions, and southern boundaries of these depressions with the South Chuya and North Chuya ranges. Strong aftershock activity is one of the main seismological peculiarities of this seismic excitation. Epicenter of the main shock (27.09.2003, 11:33UTC, $\left.M_{S}=7.3\right)$ was located on the fault boundary between Chagan-Uzun massif and North Chuya range. Two strongest aftershocks (27.09.2003, 18:52UTC, $M_{S}=6.7$ and 01.10.2003, 01:03UTC, $\left.M_{S}=7.0\right)$ took place in NW direction at the fault boundary between Kurai intermountain depression and North Chuya range. As a result of aftershock activity the fault boundaries between western part of Chuya depression and South Chuya range, between North Chuya range and Kurai depression, between North Chuya range and Chagan-Uzun massif were activated as well as fault boundaries between inner tectonic blocks of Kurai depression. The epicenters of the aftershocks shaped oval with a NW-SE orientation of the long axis (Emanov et al 2009). Down to the depth of about $20 \mathrm{~km}$ the fault line was slightly inclined towards the Chagan-Uzun massif.

The earthquake triggered a system of surface ruptures of about $70 \mathrm{~km}$ length which coincides with aftershock cloud. Southeastern terminus of rupture zone is located in the Irbistu valley where ruptures abruptly change their direction to latitudinal (Rogozhin et al 2008).

The most distant rupture (NW direction, $1 \mathrm{~km}$ length, $0.15 \mathrm{~m}$ width in 2010) we have detected at the foot of the Sajlugem range $35 \mathrm{~km}$ eastward from the southeastern terminus of rupture area. Most likely it was generated by the main shock, which epicenter is located most closely (in comparison with the epicenters of two other strongest shocks). If this rupture is the primary seismotectonic deformation, then the length of area of ruptures generated by the 2003 Chuya earthquake would be about $100 \mathrm{~km}$. Nevertheless we suppose that this rupture was renewed as a result of resonance vibrations. Similar ruptures were reported by (Rogozhin et al 2008) on the northern periphery of the Chuya intermountain depression. This thesis is also supported by its formation in unconsolidated deposits which are presented by loose talus sediments.

The ruptures described within giant multievent Sukor paleodeformation most likely have a seismic gravitational genesis. These ground effects were generated by one of the strong aftershocks which reactivated the fault boundaries of the Central Kurai neotectonic foreberg within the Kurai intermountain depression. Mentioned ruptures form a single line with the epicenters of these aftershocks.

At the same time ruptures discovered in the eastern part of the Chagan-Uzun massif can be classified as primary seismotectonic ruptures generated by the main shock. They are located 13 - $16 \mathrm{~km}$ eastward from its epicenter and are stretched in sublatitudinal direction practically completely coincide with the long axis of the rhomboid Chagan-Uzun massif. Studied deformation patterns argue for its rotation clockwise, which accompanied the right lateral displacement along the main dextral strike-slip fault of NW direction. Most likely such rotation affects not only the Chagan-uzun massif by itself but also (with different rates) separate smaller tectonic blocks in its inner structure. Such rotation could explain the circle shape of faults, which is inherited by Kara-Ajry and Kyzylchin river valleys. In 2003 similar rotation patterns were detected on the Taldura - Kuskunur watershed in the Uzuk area, where the most impressive ruptures were generated. Tension crack with the opening width of about 5-6 m went directly along the graben, which was developed as a result of repeated seismic excitations during the Holocene (Rogozhin et al 2007).

Similar conclusion about rotation of the Chagan-Uzun massif clockwise during geological time was previously obtained by (Buslov et al 1999) on the basis of topographic analysis. Thus 
same direction of seismotectonic movements within the SE Altai (same mechanisms of seismic excitations with similar kinematics of surface disturbances) could be stated since at least the late Pleistocene-Holocene.

Taking into account primary seismotectonic deformations described within the Chagan-Uzun massif and Taldura river valley the width of the rupture zone generated by the 2003 Chuya earthquake reaches now $25 \mathrm{~km}$. Our results allow us to specify parameters of rupture zone and determine the seismic origin of some landforms, which have a long evolution (PleistoceneHolocene). Our data also support thesis about repeated reactivation of the same earthquake source zones within high mountain southeastern part of Russian Altai during the Holocene.

\subsection{Paleoseismogeological investigations and absolute dating of ground effect and associated sediments of strong prehistoric earthquakes in the epicenter zone of the 2003 Chuya earthquake}

Twenty-five newly obtained radiocarbon dates and results of tree ring analysis cover the period from about 4,000 cal. BP till present time. By now we have obtained just few radiocarbon dates of ground effects related to strong earthquakes that occurred in the first half of the Holocene. This can be explained by worse preservation of landforms and features induced by ancient shocks. So in this paper we present dating results only for the last 4,000 years.

It should be also noted that accuracy of the radiocarbon method doesn't allow estimating the precise earthquake ages, but it is acceptable for reliably distinguishing the time of formation of ground effects associated with different earthquakes. This is important for marking time intervals for single seismic events and then for calculating the recurrence interval of strong earthquakes.

Dendrochronologically obtained date of a previously unknown strong medieval earthquake presented in section 4.3 was verified by radiocarbon dating. The dendrochronologically obtained date of the 1532 seismic event lies within the time range determined by radiocarbon ages of seismically cut fossil soils (IGAN 4090,
IGAN 4105) overlaid by an undistorted one (SOAN 8659), which were exhumed in one of outcrops within the giant landslide triggered by the 2003 Chuya earthquake in the Taldura valley. Moreover, radiocarbon age of paleosoils buried in a colluvium wedge within the modern landslide in the Taldura valley is interpreted as the date of a strong prehistoric earthquake $(370 \pm 30$ IGAN 3007 (Rogozhin et al 2007)) and also supports this thesis. After calibration the date is cal. AD $1540 \pm 93$. Another evidence of this medieval seismic event was detected within the southern flank of the Central Kurai neotectonic foreberg. $1.5 \mathrm{~m}$ scarp of active fault was dissected by trenches (Rogozhin and Platonova 2002). A cross section of ancient fault area represents a set of three-four steep and more flat reverse faults. Radiocarbon ages of wooden splinters and charcoals from peat layers cut by these reverse faults $(324 \pm 30$ IGAN 1692 and $345 \pm 30$ IGAN 1702) indicate the formation of the ancient fault area after cal. AD 1466.

Thus geological evidences of the strong medieval earthquake are presented $i$ ) at the cross points of the fault boundaries of the Chagan-Uzun massif with the fault boundaries of the Chuya intermountain depression and South Chuya range; ii) within the inner structure of the Chagan-Uzun massif along its northern border (in the Arydjan valley); and iii) at the southern flank of the Central Kurai neotectonic foreberg. The traced length of rupture zone about $70-75 \mathrm{~km}$ allows to assume the magnitude of this seismic event as about 7.5 (Rogozhin and Platonova 2002).

The obtained ages of the oldest trees and estimated minimum ages of the largest seismically induced landslides in the Arydjan valley don't allow clear correlation with the known earthquakes identified by regional paleoseismogeological data. Most likely they are related to the paleoearthquakes that caused ruptures and fossil soil deformations in the Kuskunur valley and in the Uzuk area (Kuskunur - Taldura watershed). Paleosoils in colluvium wedges and pressure ridges buried by coarsegrained material have radiocarbon ages $1,280 \pm 30$, 1,160 $\pm 30,1,100 \pm 30$ (IGAN 2818, 2980, 2983) (Rogozhin et al 2007). Fossil soils in colluvium wedge along tectonic scarp at the foot of the 
Central Kurai neotectonic foreberg has similar

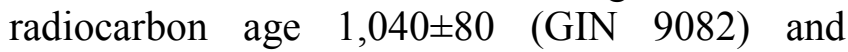
indicate the date of strong prehistoric earthquake (Rogozhin and Platonova 2002). Calibrated ages indicate that strong past earthquakes, which caused these surface disturbances, struck the SE Altai between cal. AD 661 and cal. AD 1169.

Our own paleoseismogeological investigations also support this thesis. The radiocarbon ages of fossil soil with charcoal and buried peat layer in the proximal part of the giant landslide triggered by the 2003 Chuya earthquake in the Taldura valley $(1035 \pm 45,770 \pm 40$ (SOAN $8664,8673)$ ) return the minimal possible age of prehistoric earthquake which caused the lake and peat bog formation. The radiocarbon age of charcoal from seismically deformed fossil soil within this landslide is $1,460 \pm 70$ (IGAN 4092). Thus we can assert that strong earthquakes struck the SE Altai between cal. AD 430 and cal. AD 1289. Probably one of these earthquakes triggered the landslides studied in the Arydjan valley.

Our analysis of ground effects of strong prehistoric earthquakes supports previously published data on high regional seismicity (Rogozhin and Platonova 2002, Rogozhin et al 2007, 2008) and argue for the repeated reactivation of the same earthquake source zones during the Holocene. Radiocarbon dates obtained together with previously published ones clarify the chronology of seismic events within the SE Altai (Fig. 9). Strong earthquakes occurred here about 600-700, 1,300-1,500, 2,400-2,700, 3,4003,700 and $3,800-4,200$ cal. BP. It should be mentioned that due to specific problems of applying radiocarbon technique for dating young events (Wagner 1998) several too young radiocarbon dates (about 200 years) presented in some publications (Rogozhin and Platonova 2002, Rogozhin et al 2007, 2008) couldn't be utilized for reliable time distinguishing of ground effects for the seismic events of the recent past. Thus reconstructed dates of prehistoric seismic events together with the dendrochronologically obtained age of the medieval earthquake allow estimating the recurrence interval of strong earthquakes in the SE Altai as about 400 years for the last 4000 years.

Paleoseismogeological investigations in adjusted seismically active areas of the Mongolian Altai reveal traces of several more strong $(M \geq 8)$ earthquakes. In the epicenter zone of the 1931 Fuyun earthquake $(M=8.0)$ at the western part of the Mongolian Altai, the historical and paleoseismological data evidence for presence of five such earthquakes over the last 10,000 years (Ge et al 1996, Rogozhin et al 2012). Five strongest seismic events with $M \geq 8$ over the last 7,500 years, including the 1761 Great Mongolian earthquake, were also reconstructed in
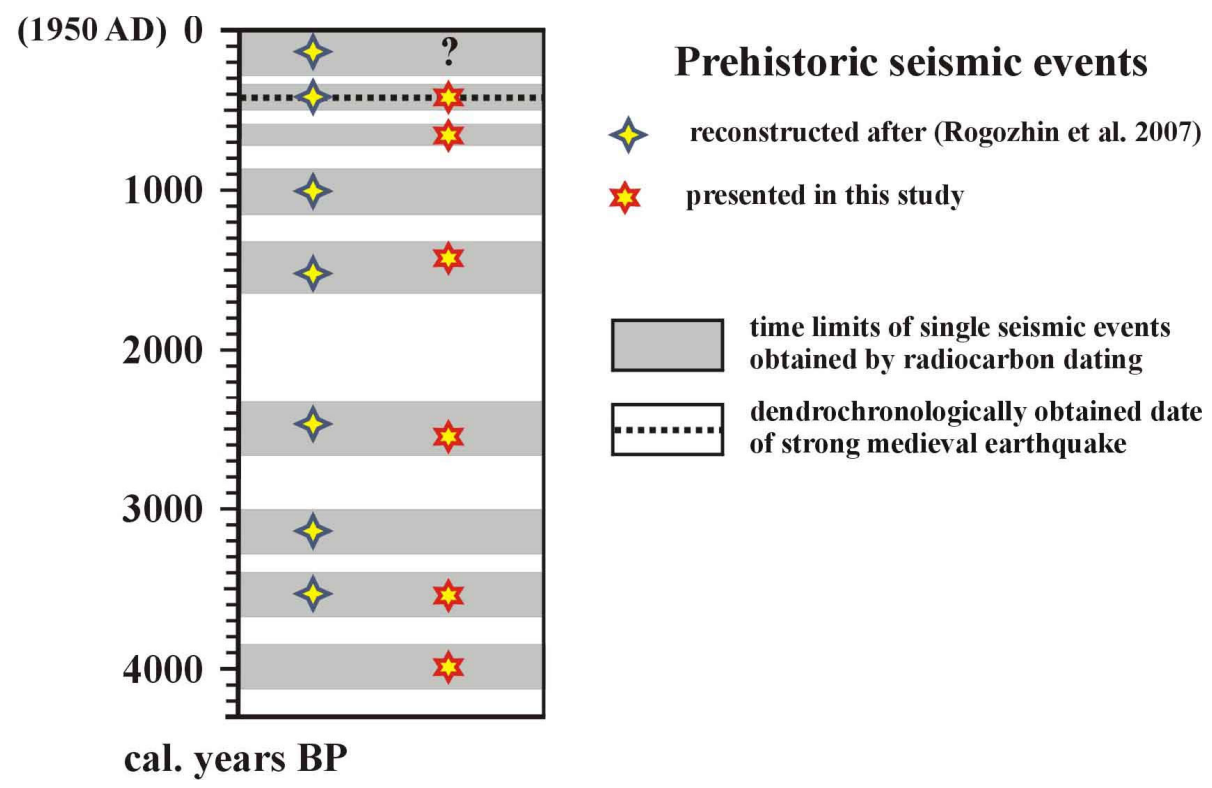

years BP

Figure 9. Reconstructed dates of strong prehistoric earthquakes within the SE Altai, obtained by radiocarbon method and dendrochronological analysis 
the eastern part of the Mongolian Altai (Rogozhin et al 2013). The specified recurrence interval of strong earthquakes for the SE Altai correlates with these data published for neighboring areas of Mongolian Altai. It is shorter than intervals for adjusted seismically active areas of the Mongolian Altai due to smaller magnitudes of strongest shocks.

\section{Conclusion}

This paper presents the results of our geomorphological, paleoseismogeological, and geochronological investigations in the high mountain, seismically active southeastern part of Russian Altai, within the epicenter zone of the 2003 Chuya earthquake.

Discovering of previously unknown ground effects of the 2003 Chuya earthquake $\left(M_{S}=7.3\right)$ including primary seismotectonic deformations allowed specifying kinematics and parameters of rupture zone associated with this the strongest historical seismic event in the SE Altai. Primary seismotectonic deformations were described on the surface of the Chagan-Uzun massif, which separates Kurai and Chuya intermountain depressions. Studied deformation patterns indicate clockwise rotation of this block during general right lateral displacements along the main dextral strike-slip fault, which were realized during 2003 seismic excitation. Taking into consideration presented ground effects the width of the rupture zone is about $25 \mathrm{~km}$.

Studying of unknown effects of strong prehistoric earthquakes preserved in sediments of the largest landslide triggered by the 2003 earthquake supports previously published thesis about repeated reactivations of the same earthquake source zones within the SE Altai during the Holocene.

Numerous new radiocarbon dates together with the first results of applying dendroseismological approach as well as previously published radiocarbon ages confirm the high occurrence of strong $(M \geq 7)$ earthquakes in the region. The recurrence interval of these seismic events is about 400 years for the last 4,000 years. These data argue for the high Holocene seismicity of the SE Altai and define the Chagan-Uzun massif as one of the major regional seismogenic structures.

\section{Acknowledgement}

A.F. Emanov, the head of the Altai-Sayan branch of the Geophysical survey SB RAS, Novosibirsk, is kindly thanked for his assistant in organizing of field researches. We would like to thank also L.A. Orlova (IGM SB RAS, Novosibirsk), E.P. Zazovskaya (IG RAS, Moscow) for the radiocarbon dating, and V.S. Myglan, V.V. Barinov (Siberian Federal University, Krasnoyarsk) for dendrochronological dating. The study was partly funded by Russian Foundation for Basic Researches (grants 15-05-06028; 16-05-01035).

\section{References}

Agatova, A.R., I.S. Novikov, E.M. Vysotsky and A.S. Gibsher, 2004. Geomorphologic effects of the 27 September and 1 October 2003 earthquakes in Gorny Altai. Geomorfologiya, 3: 3 - 12. (in Russian).

Agatova, A.R., R.K. Nepop and E.M. Vysotsky, 2006. Seismogravitational paleodislocations in the Chagan-river valley (SE Altai). Geomorfologiya, 4: 53 - 62. (in Russian).

Agatova, A.R., R.K. Nepop, I.Yu. Slyusarenko, V.S. Myglan, A.N. Nazarov and V.V. Barinov, 2014a. Glacier dynamics, palaeohydrological changes and seismicity in southeastern Altai (Russia) and their influence on human occupation during the last 3000 years. Quaternary International, 324: 6 - 19.

Agatova, A.R., R.K. Nepop, V.V. Barinov, A.N. Nazarov and V.S. Myglan, 2014b. The first dating of strong Holocene earthquakes in Gorny Altai using long-term tree-ring chronologies. Russian Geology and Geophysics, 55: 1059 - 1067.

Arslanov, A.A., 1987. Radiocarbon: Geochemistry and Geochronology. Leningrad State University Publisher, Leningrad. 298p. (in Russian).

Burbank, D.W. and Anderson, R.S., 2001. Tectonic Geomorphology. Blackwell 
Publishing, Oxford, UK.

Buslov, M.M., V.S. Zykin, I.S. Novikov and D. Delvo, 1999. Structural and geodynamic features of Cenozoic formation of Chuya intermountain depressions, Gorny Altai. Russian Geology and Geophysics, 40(12): 1720 - 1736.

Butvilovsky, V.V., 1993. Paleogeography of the Last Glaciation and the Holocene of Altai: a catastrophic events model. Tomsk University Press, Tomsk. 253p. (in Russian).

Emanov, A.A., E.V. Leskova, A.F. Emanov and A.V. Fateev, 2009. Structural elements and phases of the aftershock process of the Chuya earthquake. Physical Mesomechanics, 12(1): $29-36$.

Ge, S., M. Bo, F. Zheng and F. Luo, 1996. The Koktogay Ertay Fault, Xinjiang, China. J. Earthquake Prediction Res, 5(4): 470 - 506.

McCalpin, J.P., 2009. Paleoseismology. $2^{\text {nd }}$ edition. Elsevier, San Diego.

Narozny, Yu.K. and A.V. Osipov, 1999. Oroclimatic conditions of the Central Altai glaciations. News of Russian Geographical Society, 131(3): 49 - 57. (in Russian).

Nepop, R.K. and A.R. Agatova, 2008. Estimating magnitudes of prehistoric earthquakes from landslide data: first experience in southeastern Altai. Russian Geology and Geophysics, 49(2): 144 - 151.

Ostanin, O.V., 2007. Modern evolution of high mountain systems (by the example of Central and Southeastern Altai). PhD thesis. Barnaul: Publishing house of Altai State University, 195p. (in Russian).

Permafrost-hydrogeological Map, scale 1:200000, 1977. Novosibirsk, Department of Funds Western Siberian Geological administration, 18195.

Reimer, P., M. Baillie, E. Bard, A. Bayliss, J. Beck, P. Blackwell, C.B. Ramsey, C. Buck, G. Burr, R. Edwards, M. Friedrich, P. Grootes, T. Guilderson, I. Hajdas, T. Heaton, A. Hogg, K. Hughen, K. Kaiser, B. Kromer, F. McCormac, S. Manning, R. Reimer, D. Richards, J. Southon, S. Talamo, C. Turney, J. Plicht and C. Weyhenmeyer, 2009. IntCal09 and Marine09 radiocarbon age calibration curves, 0-50,000 years cal BP. Radiocarbon,
51(4): $1111-1150$.

Rogozhin, E.A. and S.G. Platonova, 2002. Strong earthquake source zones of Gorny Altai in the Holocene. UIPE RAS, Moscow, 130p. (in Russian).

Rogozhin, E.A., A.N. Ovsyuchenko, A.V. Marahanov and E.A. Ushanova, 2007. Tectonic setting and geological manifestations of the 2003 Altai earthquake. Geotectonics, 47(2): 87 - 104.

Rogozhin, E.A., A.N. Ovsyuchenko and A.V. Marahanov, 2008. Major earthquakes of the southern Gorny Altai in the Holocene. Izv. Physics Solid Earth, 44(6): 469 - 486.

Rogozhin, E.A., S. Zhung and S.N. Rodina, 2012. Correlation of seismotectonic features of the Gorny and Mongolian Altay, Issues of Engineering Seismology, 39(3): 5 - 20. (in Russian).

Rogozhin, E.A., A.S. Lar'kov, S. Demberel and B. Battulga, 2013. Recurrence of strong earthquakes in the active Hovd fault zone, Mongolian Altay. Geotectonics, 47(5): 340 350 .

Shiyatov, S.G., E.A. Vaganov, A.V. Kirdjanov, V.B. Kruglov, V.S. Mazepa, M.M. Naurzbaev and R.M. Khantemirov, 2000. Methods of dendrochronology. Part Krasnojarsk University press, Krasnojarsk. (in Russian).

Solonenko, V.P., 1973. Earthquakes and relief. Geomorfologiya, 4: 3 - 13. (in Russian).

Stuiver, M. and P.J. Reimer, 1993. Extended C14 data-base and Revised Calib 3.0 C-14 Age Calibration Program. Publisher, city, country

Wagner, G.A., 1998. Age Determination of Young Rocks and Artifacts. Springer, Berlin Heidelberg.

Zhalkovsky, N.D., and V.I. Muchnaya, 1975. Energy distribution of earthquakes and seismic activity in the Altai-Sayan area. Seismicity of the Altai-Sayan area. Nauka, Novosibirsk, 5 - 15. (in Russian).

Zhalkovsky, N.D., G.A. Chernov and V.I. Muchnaya, 1978. Seismic risk mapping in the Altai-Sayan Mountain Province. Seismogeology of the Eastern Altai-Sayan Mountain Province. Nauka, Novosibirsk, 79 90. (in Russian). 